\title{
Chlamydial infection of the male urethra
}

\author{
J. D. ORIEL, P. REEVE^, J. T. WRIGHTt, AND J. OWEN \\ From the Department of Genito-urinary Medicine, University College Hospital, London
}

\section{Summary}

Urethral specimens from 477 men were collected with endourethral swabs and examined for Chlamydia trachomatis by cell culture on McCoy cells pretreated with idoxuridine. Of these men, 141 had gonococcal urethritis, 262 non-gonococcal urethritis (NGU), and 74 showed no evidence of urethritis.

Of 118 men with heterosexually acquired gonococcal urethritis, thirty ( 25 per cent.), and of 23 men with homosexually acquired gonococcal urethritis, five ( 22 per cent.), yielded $C$. trachomatis from the urethra.

Urethral specimens from 240 heterosexual men with NGU were examined, and 118 (49 per cent.) yielded C. trachomatis. Of these 240 men, 140 gave a past history of gonococcal or nongonococcal urethritis and 67 (48 per cent.) of these were positive for $C$. trachomatis; no past history was given by 100 men, of whom 51 were positive for $C$. trachomatis. Of the 240 heterosexual men with NGU, 81 had had symptoms for 7 days or more before examination, of whom 48 (59 per cent.) yielded isolates of $C$. trachomatis, and $145 \mathrm{had}$ had symptoms for less than 7 days, of whom 59 (41 per cent.) yielded isolates. Of fourteen asymptomatic men, three were positive for $C$. trachomatis. Of 22 homosexual men with NGU, seven (32 per cent.) yielded C. trachomatis.

C. trachomatis was recovered from the urethra in three ( 5 per cent.) of sixty heterosexual men without urethritis, and none of fourteen homosexual men without urethritis yielded $C$. trachomatis.

\section{Introduction}

Infection of the human genital tract by $C$. trachomatis has received increasing attention in the last few years, and several investigators have reported the results

Received for publication July 15,1975

Address for reprints: J. D. Oriel, M.D., Department of Genito-urinary Medicine, University College Hospital, London WC1E 6AU

*Present address: Sandoz Forschungsinstitut, A-1235, Vienna, Austria tPresent address: Department of Obstetrics and Gynaecology, Whittington Hospital, London, N19 of culture in irradiated McCoy cells of urethral specimens obtained from men with non-gonococcal urethritis (NGU), gonococcal urethritis, and from control groups without urethritis (Table I). The proposition that $C$. trachomatis is an important cause of NGU is supported by the demonstration of the agent in a significant proportion of men with NGU, whereas in comparable groups of men without urethritis the isolation rate appears to be very low. In most of the studies of men with NGU no distinction has been made between those who give a past history of gonococcal or nongonococcal urethritis and those who do not, and the effect of a past history of urethritis on the isolation of $C$. trachomatis in a subsequent attack is therefore not known. $C$. trachomatis has also been recovered from men with gonococcal urethritis, in whom the isolation rate has been shown to be lower than in men with NGU; several investigators have noted that men with gonococcal urethritis who also have a chlamydial infection are particularly liable to develop post-gonococcal urethritis (Richmond, Hilton, and Clarke, 1972; Oriel, Reeve, Thomas, and Nicol, 1975). Little information is available on the isolation of $C$. trachomatis from the urethra in men with homosexually acquired disease.

The recovery of $C$. trachomatis from the urethra depends on the technique used for specimen collection, the conditions under which the specimens are stored before inoculation of the cell monolayers, and the sensitivity of the cell culture system itself. Dunlop, Vaughan-Jackson, and Darougar (1972a) have stated that an endourethral curette or cotton-wool-tipped wire swab yields a higher number of specimens positive for $C$. trachomatis than meatal swabs, although Richmond and others (1972) and Schachter, Hanna, Hill, Massad, Sheppard, Conte, Cohen, and Meyer (1975) obtained good results with meatal swabs in men with NGU, and Oriel, Reeve, Powis, Miller, and Nicol (1972) noticed little difference between endourethral curettes and meatal swabs in this respect. However, for the collection of urethral specimens from control groups, meatal swabs are unlikely to collect adequate amounts of material, and a curette or endourethral swab is preferable.

The cell-culture system for the isolation of $C$. trachomatis has recently been simplified by pretreating 
TABLE I Isolation of Chlamydia trachomatis from men with non-gonococcal Urethritis (NGU), gonococcal urethritis $(G)$, and no urethritis by culture on irradiated McCoy cells

\begin{tabular}{|c|c|c|c|c|c|c|}
\hline \multirow{2}{*}{ Authors } & \multirow{2}{*}{ Date } & \multirow{2}{*}{$\begin{array}{l}\text { Diagnostic } \\
\text { category }\end{array}$} & \multirow{2}{*}{$\begin{array}{l}\text { Specimen } \\
\text { collection }\end{array}$} & \multirow{2}{*}{$\begin{array}{l}\text { No. of patients } \\
\text { examined }\end{array}$} & \multicolumn{2}{|c|}{$\begin{array}{l}\text { Chlamydia } \\
\text { isolates }\end{array}$} \\
\hline & & & & & No. & Per cent. \\
\hline Gordon and Quan & 1971 & NGU & Various methods & 84 & 19 & 23 \\
\hline $\begin{array}{l}\text { Philip, Hill, Greaves, Gordon, Quan, Gerloff, } \\
\text { and Thomas }\end{array}$ & 1971 & NGU & Meatal swab & 31 & 7 & 23 \\
\hline Dunlop, Vaughan-Jackson, Darougar, and Jones & $1972 \mathrm{~b}$ & NGU & Curette & 99 & 44 & $44 \cdot 5$ \\
\hline \multirow[t]{2}{*}{ Oriel and others } & 1972 & $\begin{array}{l}\text { NGU } \\
\text { (first attack) }\end{array}$ & Curette & 98 & 35 & 36 \\
\hline & & & Meatal swab & 37 & 14 & 38 \\
\hline Richmond and others & 1972 & NGU & Meatal swab & 103 & 40 & 39 \\
\hline Schachter and others & 1975 & $\begin{array}{l}\text { NGU } \\
\text { (with discharge) }\end{array}$ & Meatal swab & 42 & 24 & 57 \\
\hline Richmond and others & 1972 & G & Meatal swab & 99 & 32 & 32 \\
\hline Oriel and others & 1975 & G & Meatal swab & 44 & 11 & 25 \\
\hline Schachter and others & 1975 & G & Meatal swab & 18 & 2 & 11 \\
\hline Richmond and others & 1972 & No urethritis & Meatal swab & 92 & 5 & 5 \\
\hline Oriel and others & 1972 & No urethritis & Curette & 31 & $\mathbf{0}$ & \\
\hline Schachter and others & 1975 & No urethritis & Meatal swab & 57 & 0 & \\
\hline
\end{tabular}

McCoy cells with idoxuridine (IUDR) as an alternative to irradiation (Wentworth and Alexander, 1974). In addition, the effects on chlamydial isolation of storing clinical specimens at $+4^{\circ}$ and $-70^{\circ} \mathrm{C}$. and of the centrifugal force used to infect cell monolayers have been studied and optimal procedures defined (Reeve, Owen, and Oriel, 1975). These refinements in laboratory technique have produced a simple and sensitive cell-culture system which is well suited to the examination of large numbers of clinical specimens.

In the present investigation we have used these modifications in clinical and laboratory procedure to examine urethral specimens from men in the following categories:

(1) Heterosexual men with gonococcal urethritis, with and without a past history of urethritis;

(2) Homosexual men with gonococcal urethritis;

(3) Heterosexual men with NGU, with and without a past history of urethritis;

(4) Homosexual men with NGU;

(5) Control groups of heterosexual and homosexual men without urethritis.

\section{Material and methods}

\section{PATIENTS}

The patients were all seen in the Department of GenitoUrinary Medicine, University College Hospital, between July, 1974, and March, 1975.The criteria used for the diagnostic groups were as follows

\section{Gonococcal urethritis}

The presence of intracellular Gram-negative diplococci on a urethral smear with positive cultures for Neisseria gonorrhoeae;

\section{Non-gonococcal urethritis}

Evidence of significant urethritis shown by the presence of at least ten polymorphonuclear leucocytes per highpower field ( $\times 100$ objective) in a urethral smear, with no evidence of $N$. gonorrhoeae on microscopy or culture;

\section{No urethritis}

Patients who attended the Department at the same time as the other groups, but in whom no evidence of significant urethritis was found. Early morning examinations were performed on some, but not all, of these control patients. The majority of these men showed no evidence of genital infection and had attended requesting routine examination, but a small number had genital warts or pediculosis pubis.

No men were included in any of the three diagnostic groups if they had intrameatal warts, genital herpes, or genital candidosis, or if they had taken any antibiotics during the 2 months before examination. Since the incidence of trichomoniasis in our male patients with NGU is known to be very low (less than 1 per cent.), tests for Trichomonas vaginalis were not undertaken during this investigation.

When the history was taken, each patient was asked whether there had been a change of partner (i.e. intercourse with a new sexual contact) during the 4 weeks before his symptoms began or, in the case of asymptomatic patients, before he came to the Department. The majority of men could be categorized as 'acknowledging partner change' or 
'not acknowledging partner change' without difficulty. It is true that in a few men the incubation period of NGU may be longer than 4 weeks (Oriel, and others, 1972), but the number of these is too small to offset the advantages of this simple system of recording the case history.

\section{SPECIMENS}

Specimens, including those for culture for $C$. trachomatis were collected at the patient's first attendance, although additional early morning tests were needed to demonstrate significant urethritis in some men. A urethral specimen was first collected with a disposable plastic loop (NUNC products) and spread on a slide, and then a culture medium for $N$. gonorrhoeae was inoculated. A cotton-wool tipped wire endourethral swab (Medical Wire and Equipment Co. Ltd.) for chlamydial isolation was then passed into the urethra as far as was possible without causing undue discomfort, usually 4 to $5 \mathrm{~cm}$., and placed in a $2 \mathrm{ml}$. bottle of transport medium (Reeve and others, 1975), the wire being cut off with sterilized wire cutters. These specimens were stored at $+4^{\circ} \mathrm{C}$. until the cell cultures were inoculated.

\section{LABORATORY PROCEDURES}

Urethral smears were stained by Gram's method and examined for intracellular Gram-negative diplococci. Cultures for $N$. gonorrhoeae were performed on modified Thayer-Martin medium (Phillips, Humphrey, Middleton, and Nicol, 1972). Cell cultures for $C$. trachomatis were normally inoculated within $4 \mathrm{hrs}$ of collection of the specimens. Details of the preparation of IUDR-treated McCoy cells and of the isolation procedure followed have been described elsewhere (Reeve and others, 1975).

\section{Results}

MEN WITH GONORRHOEA

Specimens for culture for C. trachomatis were obtained from 141 men with gonococcal urethritis, of whom 118 were heterosexual and 23 homosexual (Table II).

\section{Heterosexual men}

The average age of the 118 heterosexual men was 27.3 yrs. Eleven were Negro, five Asian, and the remainder Caucasian. C. trachomatis was isolated from thirty (25 per cent.) of them.

TABLE II Isolation of C. trachomatis from men with gonococcal urethritis

\begin{tabular}{|c|c|c|c|c|}
\hline \multirow[t]{2}{*}{ Category } & \multirow[t]{2}{*}{$\begin{array}{l}\text { Past history of } \\
\text { urethritis }\end{array}$} & \multirow[t]{2}{*}{$\begin{array}{l}\text { No. of } \\
\text { patients }\end{array}$} & \multicolumn{2}{|c|}{$\begin{array}{l}\text { Patients yielding } \\
\text { C. trachomatis } \\
\text { on cell culture }\end{array}$} \\
\hline & & & No. & Per cent. \\
\hline \multirow[t]{2}{*}{ Heterosexual } & $\begin{array}{l}\text { Present } \\
\text { Absent }\end{array}$ & $\begin{array}{l}59 \\
59\end{array}$ & $\begin{array}{l}14 \\
16\end{array}$ & $\begin{array}{l}24 \\
27\end{array}$ \\
\hline & Total & 118 & 30 & 25 \\
\hline \multirow[t]{2}{*}{ Homosexual } & $\begin{array}{l}\text { Present } \\
\text { Absent }\end{array}$ & $\begin{array}{r}15 \\
8\end{array}$ & $\begin{array}{l}3 \\
2\end{array}$ & 二 \\
\hline & Total & 23 & 5 & 22 \\
\hline
\end{tabular}

A past history of urethritis was given by 59 men; 38 gave a history of gonococcal urethritis, seven of NGU, six of both, and eight of urethritis of unknown cause. Of these 59 men, fourteen (24 per cent.) yielded $C$. trachomatis. No past history was given by the other 59 men, of whom sixteen (27 per cent.) yielded $C$. trachomatis.

Of the 118 heterosexual men with gonococcal urethritis, 102 (86 per cent.) admitted partner change within 4 weeks of the appearance of symptoms, and 24 yielded $C$. trachomatis; sixteen men, of whom six yielded $C$. trachomatis, denied partner change.

It was not possible to relate chlamydial isolation to the duration of symptoms in this group of patients, as only eleven of them attended more than 7 days after their symptoms began.

\section{Homosexual men}

23 men with homosexually acquired gonococcal urethritis were studied. Their average age was $27 \cdot 4$ yrs and all were Caucasian. C. trachomatis was recovered from five (22 per cent.).

A past history of urethritis was given by fifteen men of whom twelve gave a history of gonococcal urethritis, one of NGU, and two of both. Of these fifteen men, three were positive for $C$. trachomatis. No past history was given by the other eight men, of whom two were positive for $C$. trachomatis.

A recent change of sexual partner was admitted by 21 of these 23 homosexual men with gonococcal urethritis; only two denied recent partner change.

\section{MEN WITH NON-GONOCOCCAL URETHRITIS}

Urethral specimens for culture for $C$. trachomatis were obtained from 262 men with NGU, of whom 240 were heterosexual and 22 homosexual (Table III).

\section{Heterosexual men}

The average age of the 240 heterosexual men was $29 \cdot 2$ yrs. Thirteen were Negro, six Asian, and the remainder Caucasian. Symptoms of urethritis (dysuria, urethral irritation, or urethral discharge) were

TABLE III Isolation of C. trachomatis from men with non-gonococcal urethritis

\begin{tabular}{|c|c|c|c|c|}
\hline \multirow[t]{2}{*}{ Category } & \multirow[t]{2}{*}{$\begin{array}{l}\text { Past history of } \\
\text { urethritis }\end{array}$} & \multirow[t]{2}{*}{$\begin{array}{l}\text { No. of } \\
\text { patients }\end{array}$} & \multicolumn{2}{|c|}{$\begin{array}{l}\text { Patients yielding } \\
\text { C. trachomatis } \\
\text { on cell culture }\end{array}$} \\
\hline & & & No. & Per cent. \\
\hline \multirow[t]{2}{*}{ Heterosexual } & $\begin{array}{l}\text { Present } \\
\text { Absent }\end{array}$ & $\begin{array}{l}140 \\
100\end{array}$ & $\begin{array}{l}67 \\
51\end{array}$ & $\begin{array}{l}48 \\
51\end{array}$ \\
\hline & Total & 240 & 118 & 49 \\
\hline \multirow[t]{2}{*}{ Homosexual } & $\begin{array}{l}\text { Present } \\
\text { Absent }\end{array}$ & $\begin{array}{r}15 \\
7\end{array}$ & $\begin{array}{l}3 \\
4\end{array}$ & \\
\hline & Total & 22 & 7 & 32 \\
\hline
\end{tabular}


present in 226 men, and the other fourteen were asymptomatic, having attended for routine examination. C. trachomatis was isolated from 118 of the 240 men with NGU (49 per cent.). In thirteen of the 240 men there was no evidence of urethritis at their first attendance, but this was demonstrated on early morning examination within the following 3 days; it is of interest that $C$. trachomatis was recovered from the urethra of six of these men at their first attendance.

In 100 men with NGU there was no past history of gonococcal or nongonococcal urethritis, and 51 of these yielded $C$. trachomatis (51 per cent.). A past history of urethritis was given by 140 men; thirty gave a history of gonococcal urethritis, 76 of NGU, 26 of both, and eight of urethritis of unknown cause. Of these 140 men, 67 (48 per cent.) yielded $C$. trachomatis (Table III).

In Table IV the isolation of C. trachomatis in the present attack of NGU from the 140 men who had previously had urethritis, is correlated with the stated past history. It is seen that there is no significant difference in chlamydial isolation between the various groups.

TABLE IV Isolation of C. trachomatis related to cause of previous urethritis in heterosexual men with NGU giving a past history of urethritis

\begin{tabular}{|c|c|c|c|}
\hline \multirow{3}{*}{ Past history of urethritis } & \multicolumn{3}{|c|}{ Present attack of NGU } \\
\hline & \multirow{2}{*}{$\begin{array}{l}\text { Total no. of } \\
\text { patients }\end{array}$} & \multicolumn{2}{|c|}{ Chlamydia-positive } \\
\hline & & No. & Per cent. \\
\hline $\begin{array}{l}\text { Gonococcal } \\
\text { NGU } \\
\text { Both } \\
\text { Cause uncertain }\end{array}$ & $\begin{array}{r}30 \\
76 \\
26 \\
8\end{array}$ & $\begin{array}{r}15 \\
34 \\
14 \\
4\end{array}$ & $\begin{array}{l}50 \\
45 \\
54 \\
50\end{array}$ \\
\hline
\end{tabular}

The recovery of $C$. trachomatis from men with NGU who gave a past history of urethritis might have been affected by the interval since the last attack had occurred; some men had had urethritis as recently as $\mathbf{2}$ months ago, whereas others had not had urethritis for many years. However, the isolation of Chlamydia was not significantly affected by the interval since the previous attack of urethritis (Table V).

TABLE V Isolation of C. trachomatis from heterosexual men with NGU with a past history of urethritis related to interval since last attack of urethritis

\begin{tabular}{|c|c|c|c|}
\hline \multirow{3}{*}{$\begin{array}{l}\text { Interval since last attack } \\
\text { of urethritis } \\
\text { (mths) }\end{array}$} & \multicolumn{3}{|c|}{ Present attack of NGU } \\
\hline & \multirow{2}{*}{$\begin{array}{l}\text { Total no. of } \\
\text { patients }\end{array}$} & \multicolumn{2}{|c|}{ Chlamydia-positive } \\
\hline & & No. & Per cent. \\
\hline $\begin{array}{l}2 \text { to } 6 \\
6 \text { to } 12 \\
\text { More than } 12\end{array}$ & $\begin{array}{l}14 \\
34 \\
92\end{array}$ & $\begin{array}{r}7 \\
17 \\
43\end{array}$ & $\begin{array}{l}50 \\
50 \\
47\end{array}$ \\
\hline
\end{tabular}

Of the 240 men with NGU, 81 had had symptoms for 7 days or longer before they attended, and 48 (59 per cent.) of them gave isolates of $C$. trachomatis. A duration of symptoms of under 7 days was described by 145 men, and 59 (41 per cent.) of them gave isolates. The difference between the isolation rates in these two groups is significant $\left(\chi_{1}^{2} 7 \cdot 2 ; P<0.01\right)$. Fourteen men were asymptomatic, and three ( 21 per cent.) of them gave isolates.

A change of sexual partner within 4 weeks of the onset of symptoms was admitted by 152 (63 per cent.) of the 240 men; of these 152 men, 77 (51 per cent.) yielded C. trachomatis on culture. Partner change was denied by 88 men, and 39 ( 44 per cent.) of them yielded $C$. trachomatis.

\section{Homosexual men (Table III)}

The average age of the 22 men with homosexually acquired NGU was 25.9 yrs. One was Negro, two Asian, and the remainder Caucasian. C. trachomatis was recovered from seven ( 32 per cent.) of them.

A past history of urethritis was given by fifteen men; eleven gave a history of gonococcal urethritis, two of gonococcal and non-gonococcal urethritis, and two of urethritis of unknown cause. Of these fifteen men, three were positive for $C$. trachomatis. No past history was given by seven men, of whom four were positive for $C$. trachomatis.

A recent change of sexual partner was admitted by twenty of these twenty-two homosexual men with NGU.

\section{MEN WITHOUT URETHRITIS (Table VI) \\ Heterosexual men}

Urethral specimens were collected from sixty men who were found on first attendance to have no evidence of significant urethritis; this was confirmed by early morning examination in thirteen patients. The average age of these men was 29.6 yrs. Three were Negro, two Asian, and the remainder Caucasian.

A past history of urethritis was given by 23 (38 per cent.) of the sixty men; three gave a history of gonococcal urethritis, eighteen of NGU, and two of both.

TABLE VI Isolation of C. trachomatis from men without urethritis

\begin{tabular}{|c|c|c|c|c|}
\hline Category & $\begin{array}{l}\text { Past history of } \\
\text { urethritis }\end{array}$ & $\begin{array}{l}\text { No. of } \\
\text { patients }\end{array}$ & $\begin{array}{l}\text { No. } \\
\text { Chi } \\
\text { cell }\end{array}$ & $\begin{array}{l}\text { rielding } \\
\text { mydia on } \\
\text { ulture }\end{array}$ \\
\hline \multirow[t]{2}{*}{ Heterosexual } & $\begin{array}{l}\text { Present } \\
\text { Absent }\end{array}$ & $\begin{array}{l}23 \\
37\end{array}$ & $\begin{array}{l}1 \\
2\end{array}$ & \\
\hline & Total & 60 & 3 & $(5 \%)$ \\
\hline \multirow[t]{2}{*}{ Homosexual } & $\begin{array}{l}\text { Present } \\
\text { Absent }\end{array}$ & $\begin{array}{r}10 \\
4\end{array}$ & $\begin{array}{l}0 \\
0\end{array}$ & \\
\hline & Total & 14 & $\mathbf{0}$ & \\
\hline
\end{tabular}


Of the sixty men without urethritis, 33 (55 per cent.) admitted recent partner change.

Thus, the control group appears to approximate to the group of heterosexual men with NGU in terms of age, race, past history of gonococcal or nongonococcal urethritis, and recent partner change.

Specimens from three ( 5 per cent.) of the sixty patients without apparent urethritis yielded C. trachomatis on cell culture. None of these three patients had early morning examinations, although two of them were complaining of urethral discharge, so they may have had NGU.

\section{Homosexual men}

Specimens were also collected from fourteen homosexual men without urethritis (confirmed by early morning examinations in three). Their average age was 34.9 yrs and all were Caucasian.

Eight men gave a history of gonococcal urethritis and two of NGU.

Recent partner change was admitted by twelve of the fourteen homosexual men.

Cell culture for C. trachomatis was negative in every one of the fourteen men.

\section{Discussion}

In the present investigation $C$. trachomatis was recovered from the urethra of men with gonococcal urethritis and men with NGU, but it was found, as has been reported previously, that in the absence of urethritis the isolation rate was very low. Heterosexual men with gonococcal urethritis showed an isolation rate of 25 per cent., which compares well with rates of 29 per cent. (Richmond and others, 1972) and 25 per cent. (Oriel, Reeve, and others, 1975) reported from other centres in England. In the present study, 22 per cent. of a small group of 23 men with homosexually-acquired gonococcal urethritis yielded C. trachomatis on cell culture, and there thus appears to be little difference between heterosexual and homosexual men in this respect. The best interpretation of the isolation results for men with gonococcal urethritis seems to us to be that $N$. gonorrhoeae and $C$. trachomatis are sexually transmitted at the same time, and epidemiological studies support this hypothesis (Oriel, Wright, and Reeve, 1975). The role of $C$. trachomatis in the pathogenesis of post-gonococcal urethritis has been discussed elsewhere (Oriel, Reeve, and others, 1975).

C. trachomatis was isolated from 51 per cent. of 100 heterosexual men with NGU who gave no past history of urethritis and from 48 per cent. of 140 heterosexual men with NGU who had previously had gonococcal or nongonococcal urethritis. Neither a past history of urethritis, the cause of this urethritis, nor the interval of time since it had occurred affected the isolation rate. There was, however, some indication that the isolation of $C$. trachomatis may be related to the duration of a patient's symptoms. $C$. trachomatis was recovered from 59 per cent. of 81 patients whose symptoms had been present for 7 days or more, but from only 41 per cent. of 145 men whose symptoms were of shorter duration. Richmond and others (1972) have reported similar results. The chances of isolating C. trachomatis from the urethra may well be increased by the passage of time which allows the number of infective particles to increase. This may be one of the reasons why repeated attempts at isolation in the same patient may yield an additional number of Chlamydia-positive specimens (Oriel, Reeve, and others, 1975). From the results of the present investigation we conclude that, under optimal conditions, $C$. trachomatis may be recovered with present techniques from approximately 60 per cent. of men with NGU.

Boyd, Csonka, and Oates (1958) pointed out that a clear-cut history of change of sexual partner was more often given by men with gonococcal urethritis than by men with NGU, and this was also found in this study. Recent partner change was admitted by 86 per cent. of 118 heterosexual men with gonococcal urethritis, but by only 63 per cent. of 240 heterosexual men with NGU. The discrepancy between these figures is of interest. Although the histories given by men with NGU may be misleading or falsified, or their female partners may themselves have had other sexual contacts, this applies no less to men with gonococcal urethritis. Some of the men with NGU may, however, have had incubation periods of longer than the arbitrary limit of 4 weeks which we set in defining partner change. Thus, although C. trachomatis was recovered from 44 per cent. of 88 heterosexual men who developed NGU without admitting partner change as defined, the question whether it is possible for a man to develop Chlamydiapositive NGU within a stable relationship must at present be regarded as undecided.

We were able to examine only a small number of men with homosexually acquired NGU, because among homosexuals in London gonococcal urethritis is at least four times commoner than NGU (Fluker, 1975). However, C. trachomatis was recovered from 32 per cent. of 22 patients with homosexually-acquired NGU. No information is at present available on the prevalence of $C$. trachomatis in the anal canal of the sexual contacts of such patients.

The results with improved methods of specimen collection and cell culture indicate that $C$. trachomatis is associated with approximately one-half of NGU infections and one-quarter of gonococcal urethritis infections. In our Department, this organism is now the commonest pathogen recovered from the male urethra. 
We are grateful to Dr. E. Joan Stokes for her advice and encouragement and for kindly providing laboratory facilities, and to Miss Lam Po Tang for technical assistance.

This work was supported by a grant from the Medical Research Council.

\section{References}

Boyd, J. T., Csonka, G. W., and OATES, J. K. (1958) Brit. f. vener. Dis., 34, 40

Dunlop, E. M. C., Vaughan-Jackson, J. D., and Darougar, S. (1972a) Ibid., 48, 421

$\longrightarrow,-,-$, and JoNES, B. R. (1972b) Ibid., 48, 425

FLUKER, J. L. (1975) Personal communication

GORDON, F. B., and QUAN, A. L. (1971) In 'Trachoma and Related Disorders', ed. R. L. Nichols, p. 476. Excerpta Medica, Amsterdam and New York
Oriel, J. D., Reeve, P., Powis, P., Miller, A., and Nicol, C. S. (1972) Brit. F. vener. Dis., 48, 429

$\longrightarrow$, Thomas, B. J., and Nicol, C. S. (1975) $\mathcal{f}$. infect. Dis., 131, 376

$\longrightarrow$ WRIGHT, J. T., and REEVE, P. (1975) In preparation

Philip, R. N., Hill, D. A., Greaves, A. B., Gordon, F. B., QuAN, A. L., Gerloff, R. K., and Thomas, L. A. (1971) Brit. F. vener. Dis., 47, 114

Phillips, I., Humphrey, D., Middleton, A., and Nicol, C. S. (1972) Ibid., 48, 287

Reeve, P., OWEn, J., and ORIEL, J. D. (1975) f. clin. Path., 28, 910

Richmond, S. J., Hilton, A. L., and Clarke, S. K. R. (1972) Brit. F. vener. Dis., 48, 437

Schachter, J., Hanna, L., Hill, E. C., Massad, S., ShePpard, C. W., ConTe, J. E., CohEN, S. N., and MeYer, K. F. (1975) F. Amer. med. Ass., 231, 1252

Wentworth, B. B., and AleXANDER, E. R. (1974) Appl. Microbiol., 27, 912 